\title{
Effects of Beta Glucan as Immunostimulant on Labeo Rohita Challenged with a Bacterial Pathogen Aeromonas Hydrophila
}

\author{
Sriparna Datta Ray ${ }^{\text {a, b }}$, Dola Roy ${ }^{\text {, }}$,Subharthi Pal a , Sumit Homechaudhuri ${ }^{\text {a,* }}$ \\ ${ }^{a}$ Aquatic Bioresource Research Laboratory, Department of Zoology, University of Calcutta. \\ 35 Ballygunge Circular Road, Kolkata, West Bengal - 700019, India. \\ ${ }^{\mathrm{b}}$ Department of Zoology, Sreegopal Banerjee College, University of Burdwan, Hooghly, \\ West Bengal - 712148, India. \\ *sumithomechaudhuri@gmail.com
}

\begin{abstract}
Study characterized immune responses in immunomodulated Labeo rohita fingerlings. 3\% $\beta$-glucan at a dose of $2 \mathrm{gm} \%$ was administered (i.p.) for seven consecutive days. The experimental design consisted of

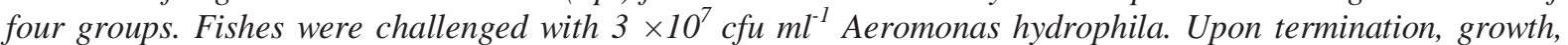
hematological and biochemical parameters were analyzed. Results showed significant increase $(p<0.05)$ in $K$ value and specific growth rate for the immune primed fishes in comparison to the other three groups, indicating positive effect of $\beta$ glucan on fish health. Total erythrocyte count, haemoglobin percentage and Haematocrit value increased significantly $(p<0.05)$ in group II in comparison to other 3 groups. Total leukocyte count and Leucokrit value showed similar pattern in which the highest significant $(p<0.05)$ value was observed in group III, followed by group II, IV and I. MCV and MCH showed highest values in group IV in comparison to group III, II and I. Significant difference was found in differential WBC counts across the 4 groups. Albumin globulin ratio and total protein content were measured which indicated that $\beta$ glucan has an enhancing effect on immune responses of Labeo rohita fingerlings. Thus the efficacy of $\beta$ glucan was found to be significant in improving the immune responses in Labeo rohita immunocompromised with Aeromonas hydrophila.
\end{abstract}

Keywords: Growth Indices, Haematology, Protein Profile, Immunomodulation, Aeromonads

\section{INTRODUCTION}

Labeo rohita (Hamilton, 1822) is a commercially important fish among the Indian Major Carps. Although, India ranks second among the world freshwater fish producers [1], it faces the challenge of fish mortality due to bacterial diseases. Among bacterial diseases, those caused by Aeromonads represents an economic threat to the aquaculture industry.

Motile Aeromonad infections have been recognized and have been referred to as Motile Aeromonad Septicemia (MAS), Motile Aeromonad Infection (MAI), hemorrhagic septicemia, red pest, and red sore [2]. Bacteriological studies on fishes affected with Epizootic Ulcerative Syndrome (EUS) have been documented by several scientists from various parts of India [3-5]. The host pathogen interaction with special emphasis to Aeromonas hydrophila has been documented [6]. Immune response of zebra fish (Danio rerio) against a newly isolated bacterial pathogen Aeromonas hydrophila has been described [7]. Knowledge concerning host immune response to Aeromonas virulence factors in humans has been documented [8].

Modern trends in Aeromonas hydrophila disease management in fish has been elaborated [9]. Several scientists have performed studies on immunostimulants to evaluate their role in immune response in fishes [10 - 29]. Effect of dietary beta $-1,3$ glucan on the growth, survival, physiological and immunological response of marron, Cherax tenuimanus has been described [30].

Biomarkers are defined as changes in biological responses that can be related to exposure to, or the toxic effects of, environmental chemicals. Biomarker responses are powerful because they integrate a wide array of environmental, toxicological and ecological factors that control and modulate exposure to, as well as effects of, environmental contaminants. Hence study using potential biomarkers has gained a lot of impetus. With most pathogenic and etiologic agents of deadly diseases acquiring resistance to currently used drugs, the development and formulation of vaccines against predominant 
infectious diseases has taken centre stage. In the present study, haematological and biochemical parameters have been chosen as potential fish biomarkers which will help us to understand the host immune response in Labeo rohita challenged with Aeromonas hydrophila. The role of $\beta$ glucan as an immunostimulant shall also be considered.

The study is one of the several important steps toward a better understanding of host-pathogen interaction and assessment of ecosystem health. The study on immunomodulation will also help to understand the effects of immunostimulants on non-specific immunity and disease of the Indian major carps under infection with Aeromonas hydrophila.

\section{MATERIALS AND METHODS}

\section{Bacterial Culture:}

The bacterial strain, Aeromonas hydrophila, MTCC 646 was collected from Microbial Type Culture Collection and Gene Bank (MTCC), Institute of Microbial Technology (IMTECH), Chandigarh, India. This strain was received as lyophilized culture and subsequently revived by adding Nutrient Broth and transferring the rehydrated culture to a Nutrient Agar medium. Consequently, streak plate method was followed to get isolated bacterial colonies [31].

\section{Fish and Experimental Condition:}

Fingerlings of Labeo rohita were collected from a local fish farm, Matsyajibi Samabyay Samity, Anandapur, Ruby, Kolkata. In the laboratory, fishes were kept in glass aquarium ( $2 \mathrm{ft} X 1 \mathrm{ft} \mathrm{X} 1 \mathrm{ft}$ ) in the Animal House and acclimatized for 7 days. Temperature was maintained at $25 \pm 1{ }^{\circ} \mathrm{C}$ and with a 12 hour light and 12 hour dark cycle. Aeration was provided to all the tanks ( 24 hours) from an air compressor and about $20 \%$ of the water was changed every day in all the experimental tanks. Dissolved oxygen $\left(\mathrm{DO}_{2}\right)$ and ammonia were monitored every week. They ranged from 5.5 to $7.6 \mathrm{mg}$ $\mathrm{O}_{2} / \mathrm{L}$ and 0.5 to $1 \mathrm{ppm}$ ammonia, and $\mathrm{pH}$ ranged from 7.5 to 8.5 throughout the experimental period. The fishes were fed with control diet free of any immunomodulant. Unutilized feed and faecal matters were siphoned out daily.

\section{Experimental Design:}

After acclimatization, the fishes were divided into 4 groups (Table 1). 10 fishes were kept in each tank at a time. There were 6 replicates for each group.

Table1. Experimental Groups

\begin{tabular}{|l|l|l|l|}
\hline SL No & Group & Details of Treatment & $\begin{array}{l}\text { Average Body weight } \\
\text { and Length }\end{array}$ \\
\hline 1 & I & Sham Operated Control fishes & \multirow{2}{*}{ $\pm 30 \mathrm{gms} ; \pm 15 \mathrm{cms}$} \\
\hline 2 & II & Fishes treated with 2\% glucan (i.p.) for seven days \\
\hline 3 & III & $\begin{array}{l}\text { Fishes treated with 2\% glucan for seven days and then } \\
\text { artificially inoculated with Aeromonas hydrophila (i.p.) }\end{array}$ & $\begin{array}{l}\text { Fishes artificially inoculated with Aeromonas hydrophila } \\
\text { (i.p.) but those which did not receive glucan treatment }\end{array}$ \\
\hline 4 & IV &
\end{tabular}

\section{Glucan Preparation:}

Fishes were given intraperitoneal injections of $2 \% \beta$-glucan (dissolved in sterile PBS) solution at $0.5 \mathrm{ml} / 100$ gm body weight for seven consecutive days.

\section{Artificial Inoculation of Aeromonas hydrophila:}

The bacterial strain MTCC 646 was cultured in nutrient broth (NB) and incubated at $37^{\circ} \mathrm{C}$ for 24 hours prior to artificial inoculation of fishes. Bacterial cells were harvested by centrifugation at 5000 $\mathrm{x} \mathrm{g}$ for $5 \mathrm{~min}$ and washed in physiological saline, PS $(0.85 \% \mathrm{NaCl})$. The strain was enumerated by correlating the OD value taken at $600 \mathrm{~nm}$ of the growing culture with the corresponding colony forming units (cfu) obtained by spread plate dilution method (Ref: OD $6001=2 \times 10^{9} \mathrm{cfu} / \mathrm{ml}$ ), following [32]. For this experiment, one sub lethal concentration $\left(3 \times 10^{7} \mathrm{cfu} / \mathrm{ml}\right)$ was made up in PS (working volume: $0.5 \mathrm{ml} / 100 \mathrm{gm}$ body weight of fish) and injected intraperitoneally (i.p.) into 6 replicates of test fish (each replicate containing 10 fishes in group III and IV) [33]. The potential fish biomarkers chosen for the study were recorded upon termination of experiment on the $7^{\text {th }}$ day of exposure and compared among the four experimental groups. 


\section{Blood and Serum Collection:}

Fishes were anaesthetized by dipping for $30 \mathrm{~s}$ in $0.1 \mathrm{ppm}$ of MS 222 suspension in water. After anaesthetizing, blood samples were collected from the caudal vein of all the fishes belonging to 4 different groups ( 4 X 10 nos). There were 6 replicates for each group. For serum, blood samples were withdrawn into Eppendorf tubes without anticoagulant in the syringe. Blood samples in Eppendorf tubes were allowed to clot at $4^{\circ} \mathrm{C}$ for an hour and were then centrifuged at $3000 \times \mathrm{g}$ for $10 \mathrm{~min}$ and the supernatant serum was collected. The serum was stored at $-20^{\circ} \mathrm{C}$ until use within 2 days.

\section{Assessment of Growth Performance:}

Fish samples were collected from each group and their condition factor $(\mathrm{K})$ and specific growth rate (SGR) were recorded [34].

\section{Determination of Haemalogical Parameters:}

Total Erythrocyte count (TEC), Total Leucocyte count (TLC), Haematocrit (PCV, Hct \%), Leucocrit (Lct \%), Haemoglobin \%, dWBC \%. The MCV, MCH values were calculated from hematological data. All the haematological parameters were determined following [33] with slight modifications.

\section{Determination of Serum Biochemical Parameters:}

Total Serum protein, Albumin, Globulin, Albumin:Globulin ratio was measured from all sets of fishes. All the biochemical parameters were determined following [33] with slight modifications.

\section{Statistical Analysis:}

Means and Standard Error (S.E.) of the means were calculated from whole range data following [35]. One way Univariate Analysis of variance (ANOVA) at 5\% level of significance and Duncan's Post Hoc test was also done to identify the homogenous means, if any using SPSS Statistics 17.0.

\section{RESUlTS AND DisCUSSION}

It is known that well supported immune system protects the fish against diseases and increases the rate of survival. Increases of phagocytic cells, lymphocyte activities, and macrophages can be listed as the common observations on fish treated with immunostimulants. We will describe the results in respect of 4 experimental groups i.e. group I (control fishes); group II ( $\beta$ Glucan treated fishes); group III (A. hydrophila challenged, prior $\beta$ Glucan treated fishes) and group IV (A. hydrophila challenged fishes).

\section{Health and Growth Parameters:}

A significant difference $(\mathrm{p}<0.05 \mathrm{df}=3$ ) was found in Condition factor $(\mathrm{K})$ among four different experimental groups of L. rohita (Table 2). Duncan's post hoc test revealed the presence of 3 subsets in case of K. Fishes of group II and IV belonged to different single subsets indicating that there were significant differences in the $\mathrm{K}$ value when it is compared pair-wise with other groups. Whereas, fishes of group I and III belonged to a single subset, indicating that there was no significant difference between them when compared pair-wise.

Condition factor $(\mathrm{K})$ is generally considered as a measurement of fish health status. In this current study, we have noticed that general health condition as well as survival of fishes administered with $\beta$ glucan was higher in group II fishes in comparison to control ones. Also, in case of A. hydrophila infection, the health status of the fishes were found to be better in the group III fished than the group IV fishes in terms of $\mathrm{K}$ value.

A significant difference ( $\mathrm{p}<0.05 \mathrm{df}=3$ ) was found in Specific Growth Rate (SGR \%) among four different experimental groups of $L$. rohita (Table 1). Duncan's post hoc test revealed the presence of 3 subsets in case of SGR. Fishes of group I and IV belonged to different single subsets indicating that there were significant differences in the SGR value when it is compared pair-wise with other groups. Whereas, fishes of group II and III belonged to a single subset, indicating that there was no significant difference between them when compared pair-wise.

So, the current study suggests that, in a condition of no stress, normal nutrition and diet can lead to higher SGR in fishes after $\beta$ glucan administration. Nevertheless, from our present experiment, the 
growth promoting effect of $\beta$-glucan is also evident. This finding is in accordance to similar work [36, $15,37]$. The present finding is in accordance with similar studies where dietary feed supplementation with both natural and commercial $\beta$ glucans has shown improvement in health, growth and general performance of different animal groups, including farmed shrimp, fish and other land animals. Fish growth has been enhanced with the use of (EcoActiva) a commercially available Beta-glucan orally in Pink snapper [15]; Beta-glucan in Rohu [38], $\beta(1,3)$ glucan in Large yellow croaker [39].

Table 2. Values of Condition Factor $(K)$ and Specific Growth Rate (SGR \%) in L. Rohita in Different Experimental Groups.

\begin{tabular}{|l|l|l|l|l|}
\hline Growth Parameters & $\begin{array}{l}\text { Group I } \\
(\text { Mean } \pm \text { SE) }\end{array}$ & $\begin{array}{l}\text { Group II } \\
(\text { Mean } \pm \text { SE) }\end{array}$ & $\begin{array}{l}\text { Group III } \\
(\text { Mean } \pm \text { SE) }\end{array}$ & $\begin{array}{l}\text { Group IV } \\
(\text { Mean } \pm \text { SE) }\end{array}$ \\
\hline Condition factor $(\mathbf{K})$ & $0.58 \pm 0.02^{\mathrm{b}}$ & $0.68 \pm 0.02^{\mathrm{c}}$ & $0.59 \pm 0.01^{\mathrm{b}}$ & $0.51 \pm 0.01^{\mathrm{a}}$ \\
\hline $\begin{array}{l}\text { Specific growth rate } \\
\text { (SGR\%) }\end{array}$ & $0.56 \pm 0.02^{\mathrm{b}}$ & $0.82 \pm 0.06^{\mathrm{c}}$ & $0.80 \pm 0.08^{\mathrm{c}}$ & $0.29 \pm 0.08^{\mathrm{a}}$ \\
\hline
\end{tabular}

Experimental groups: Group I (control fishes); Group II ( $\beta$ Glucan treated fishes); Group III (A. hydrophila challenged, prior $\beta$ Glucan treated fishes) and Group IV (A. hydrophila challenged fishes). Similar alphabets within column denote homogenous means due to Duncan's post hoc test at $5 \%$ level of significance.

\section{Haematological Parameters:}

A significant difference ( $\mathrm{p}<0.05 \mathrm{df}=3$ ) was found in Total Leucocyte Count (TLC) and Leucocrit (Lct) value among four different experimental groups of L. rohita (Table 3). Duncan's post hoc test revealed the presence of 4 different subsets in case of TLC. This indicates that there was a significant difference in the TLC value with respect to all the four experimental groups when they were compared pair-wise. In case of Lct Group II and IV belong to a single subset thus 3 different subsets were revealed by Duncan's post hoc test.

A significant difference $(\mathrm{p}<0.05 \mathrm{df}=3)$ was found in Neutrophil \%, Basophil \% and Monocyte \% among four different experimental groups of L. rohita (Table 3). Fishes of Group II, IV and Group III, IV (Table 3) belonged to single subsets indicating that there was no significant difference between them in terms of Neutrophil and Basophil counts respectively when compared pair-wise with other groups. Whereas, in case of Monocyte \% fishes of group II, III and group II, IV belonged to single subsets each which indicates that there was no significant difference between them when compared pair wise. A significant difference $(\mathrm{p}<0.05 \mathrm{df}=3)$ was found in Eosinophil \%, Large lymphocyte \% and small lymphocyte \% among four different experimental groups of $L$. rohita (Table 3 ). Duncan's post hoc test revealed the presence of 4 subsets in each of the cases. This indicates that there was a significant difference in all three different leucocytes (Eosinophil, large lymphocyte and small lymphocyte) with respect to all the four experimental groups when they were compared pair-wise.

It is known that the amount of leukocyte cells is normally lower in healthy fishes and can be used as a significant indicator for infectious diseases. When infectious disease agents such as bacteria enter the fish body the non-specific (cellular) defense system gets stimulated during the first stage of disease manifestation. In this situation, the leucocytes get increased (leucocytosis) initially in order to protect the fish body by phagocytosis and produce antibacterial chemicals to stop the agent from spreading. The significant increase in the total WBC count and the number of different leucocytes i.e. neutrophil, large lymphocytes, monocytes etc, observed in this present study signifies the fact that the innate immunity of the fish was stimulated to fight against the bacterial pathogen as the primary line of defense.

In our study, it was observed that the activities of leukocytes have increased against bacterial infection more significantly, when they were stimulated with a certain amount of $\beta$ glucan in advance compared to simple infection, which signifies the immunostimulatory activity of $\beta$ glucan. Result obtained in the present study supported other studies [14] who also reported increased WBC counts in C. carpio after treatment with herbal Azardicha indica. The in vivo activation of phagocytic cells by $\beta$-glucan might also induce other antimicrobial mechanisms, which include release of lysosomal enzymes, cationic peptides, complement components and production of reactive oxygen species [40, 41]. 
Effects of Beta Glucan as Immunostimulant on Labeo Rohita Challenged with a Bacterial Pathogen Aeromonas Hydrophila

Table 3. Values of different haematological parameters and Differential WBC \% in L. rohita in different experimental groups.

\begin{tabular}{|c|c|c|c|c|}
\hline \multicolumn{5}{|c|}{ A. Hematological Parameters } \\
\hline & $\begin{array}{l}\text { Group I } \\
(\text { Mean } \pm \text { SE })\end{array}$ & $\begin{array}{l}\text { Group II } \\
(\text { Mean } \pm \text { SE) }\end{array}$ & $\begin{array}{l}\text { Group III } \\
(\text { Mean } \pm \text { SE) }\end{array}$ & \begin{tabular}{|l|} 
Group IV \\
$($ Mean \pm SE)
\end{tabular} \\
\hline TEC $\left(10^{6} / \mathrm{ml}\right)$ & $1.28 \pm 0.03^{\mathrm{c}}$ & $1.29 \pm 0.02^{c}$ & $0.83 \pm 0.02^{b}$ & $0.62 \pm 0.02^{\mathrm{a}}$ \\
\hline $\operatorname{TLC}\left(10^{3} / \mathrm{ml}\right)$ & $5.92 \pm 0.06^{\mathrm{a}}$ & $25.17 \pm 0.33^{\mathrm{c}}$ & $27.45 \pm 0.28^{d}$ & $16.45 \pm 0.23^{b}$ \\
\hline Hb \% & $9.87 \pm 0.02^{c}$ & $10.04 \pm 0.05^{\mathrm{c}}$ & $9.56 \pm 0.13^{b}$ & $8.79 \pm 0.08^{\mathrm{a}}$ \\
\hline Het \% & $32.47 \pm 0.22^{\mathrm{c}}$ & $34.98 \pm 0.33^{\mathrm{d}}$ & $27.71 \pm 0.18^{b}$ & $23.87 \pm 0.17^{\mathrm{a}}$ \\
\hline Let \% & $1.05 \pm 0.02^{\mathrm{a}}$ & $1.28 \pm 0.04^{b}$ & $1.76 \pm 0.02^{\mathrm{c}}$ & $1.25 \pm 0.03^{b}$ \\
\hline MCV (fL) & $274.6 \pm 3.4^{\mathrm{a}}$ & $296.87 \pm 13.3^{\mathrm{a}}$ & $388.2 \pm 12.5^{b}$ & $448.5 \pm 13.4^{\mathrm{c}}$ \\
\hline MCH (pg/cell) & $77.38 \pm 0.97^{\mathrm{a}}$ & $114.1 \pm 2.7^{b}$ & $119.9 \pm 3.21^{b}$ & $142.4 \pm 5.24^{\mathrm{c}}$ \\
\hline \multicolumn{5}{|c|}{ B. Differential WBC \% } \\
\hline & $\begin{array}{l}\text { Group I } \\
(\text { Mean } \pm \text { SE) }\end{array}$ & $\begin{array}{l}\text { Group II } \\
(\text { Mean } \pm \text { SE) }\end{array}$ & $\begin{array}{l}\text { Group III } \\
(\text { Mean } \pm \text { SE) }\end{array}$ & $\begin{array}{l}\text { Group IV } \\
\text { (Mean } \pm \text { SE) }\end{array}$ \\
\hline Neutrophil & $26.56 \pm 0.7^{\mathrm{a}}$ & $31.66 \pm 0.41^{b}$ & $33.60 \pm 0.26^{\mathrm{c}}$ & $31.02 \pm 0.43^{b}$ \\
\hline Eosinophil & $0.67 \pm 0.01^{\mathrm{a}}$ & $0.86 \pm 0.02^{b}$ & $1.38 \pm 0.05^{\mathrm{d}}$ & $1.02 \pm 0.01^{\mathrm{c}}$ \\
\hline Basophil & $1.45 \pm 0.03^{b}$ & $1.08 \pm 0.01^{\mathrm{a}}$ & $2.46 \pm 0.02^{\mathrm{c}}$ & $2.40 \pm 0.02^{\mathrm{c}}$ \\
\hline Large lymphocyte & $18.91 \pm 0.01^{\mathrm{a}}$ & $34.67 \pm 0.18^{d}$ & $31.91 \pm 0.24^{b}$ & $32.54 \pm 0.13^{\mathrm{c}}$ \\
\hline Small lymphocyte & $49.96 \pm 0.25^{\mathrm{d}}$ & $28.2 \pm 0.06^{b}$ & $26.98 \pm 0.30^{\mathrm{a}}$ & $29.61 \pm 0.08^{c}$ \\
\hline Monocyte & $2.43 \pm 0.05^{\mathrm{a}}$ & $3.53 \pm 0.02^{b, c}$ & $3.66 \pm 0.09^{c}$ & $3.39 \pm 0.12^{b}$ \\
\hline
\end{tabular}

Experimental groups: Group I (control fishes); Group II ( $\beta$ Glucan treated fishes); Group III ( $A$. hydrophila challenged, prior $\beta$ Glucan treated fishes) and Group IV (A. hydrophila challenged fishes). Similar alphabets within column denote homogenous means due to Duncan's post hoc test at $5 \%$ level of significance.

A significant difference $(\mathrm{p}<0.05 \mathrm{df}=3$ ) was found in Total Erythrocyte Count (TEC), Mean Corpuscular Volume (MCV) and Mean Cell Heamoglobin (MCH) among four different experimental groups of L. rohita (Table 2). Duncan's post hoc test revealed the presence of 3 subsets in case of each of the three parameters. Fishes of group I, II belonged to single subsets (Table 3) which indicates that there was no significant difference in the TEC and MCV values when compared pair-wise with other groups. Whereas, fishes of group II and III belonged to a single subset in case of $\mathrm{MCH}$, indicating that there was no significant difference between them when compared pair-wise.

An increase in $\mathrm{RBC}$ count was reported among the effects of $\beta-1,3 / 1,6$ glucan on channel cat fish $[42,43]$ which is in accordance with the current findings. In the present study, increases on RBC levels are assumed as health indicator of fish. On the other side Aerolysin, produced by some strains of $A$. hydrophila, is an extracellular, soluble, hydrophilic protein exhibiting both hemolytic and cytolytic properties. Hemolysins are exotoxic proteins produced by bacteria and their lytic activities on red blood cells are reported to be important for nutrient acquisition or for causing certain conditions such as anemia [44] Aerolysin and hemolysin genes are reported to be the putative virulence genes of $A$. hydrophila. The significant decrease $(\mathrm{p}<0.01)$ in total erythrocyte count in the $A$. hydrophila infected fish compared to the control fishes, in this study, could be attributed to the severe hemolytic activity of aerolysin protein. Similarly, infection of $A$. hydrophila producing strong $\beta$-hemolysin was reported among common carps [45]. MCV is elevated or decreased in accordance with average RBC size; i.e, low MCV indicates microcytic, normal MCV indicates normocytic and high MCV indicates macrocytic. On the other hand, the increase in MCV ( $\mathrm{p}<0.01)$ observed in this study after $A$. hydrophila infection, in comparison with control fishes could be further attributed to intense damage or cirrhosis to the liver, the largest organ in the body, responsible for filtering (removing) harmful chemical substances, producing important chemicals for the body, and other important functions. Significant increase $(\mathrm{p}<0.01)$ observed in Mean corpuscular hemoglobin $(\mathrm{MCH})$ value in $A$. hydrophila treated fishes compared to control ones, could be also be attributed to macrocytic anemia, a blood disorder in which not enough red blood cells are produced, but the ones that are present are large thus fitting more hemoglobin.

A significant difference ( $\mathrm{p}<0.05 \mathrm{df}=3$ ) was found in Haemoglobin percentage $(\mathrm{Hb} \%)$ and Haematocrit (Hct) value among four different experimental groups of L. rohita (Table 3). Duncan's post hoc test revealed the presence of 3 subsets and 4 subsets in case of $\mathrm{Hb} \%$ and Hct value 
respectively. Fishes of group I and II belonged to a single subset, indicating that there was no significant difference in terms of $\mathrm{Hb} \%$ between them when compared pair-wise. Presence of four different subsets in case of Hct value incated that there was a significant difference with respect to all the four experimental groups when they were compared pair-wise.

The significant decrease in the Hct observed in Aeromonas hydrohila treated samples, in this study, could be attributed to multiple factors viz. the destruction of the erythroblast, thereby, limiting their synthesis. Moreover the extreme reduction in total erythrocyte count alone might have also caused for the observed low haematocrit value. In this current study it was also found that there was significantly less amount of RBCs, $\mathrm{Hb}$ and $\mathrm{Hct}$ level in the group IV compared to group III, which signifies the fact there is much less haemolytic effect of $A$. hydrophila infection due to immunostimulation provided by $\beta$ glucan administration in the group III fishes. So, effect of $\beta$ glucan as a potent inducer of immunity can be observed clearly, as significantly less damage in terms of decrease of TEC, HB, Hct is caused by $A$. hydrophila infection in group III due to prior $\beta$ glucan administration in comparison to group IV, where simple A. hydrophila infection was caused

\section{Biochemical Parameters:}

A significant difference ( $<<0.05 \mathrm{df}=3$ ) was found in Total Protein content among four different experimental groups of L. rohita (Table 4). Duncan's post hoc test revealed the presence of 2 subsets in case of Total Protein content. Fishes of group I and II belonged to a single subset, indicating that there was no significant difference between them when compared pair-wise. Whereas, of group III and IV belonged to another single subset, indicating that there was no significant difference between them when compared pair-wise.

As a first line of defence, various peptides such as lysozymes, antibodies, complement factors and other lytic factors are present in serum where they prevent adherence and colonization of microorganisms [46] leading to prevention of infection and disease. Many authors have reported the enhancement of the lysozyme activity, complement activity and bactericidal activity $[47-49,12,50]$ due to administration of $\beta$-glucan.

Table 4: Values of biochemical parameters in L. rohita in different experimental groups.

\begin{tabular}{|l|l|l|l|l|}
\hline $\begin{array}{l}\text { Biochemical } \\
\text { parameters }\end{array}$ & $\begin{array}{l}\text { Group I } \\
(\text { Mean } \pm \text { SE) }\end{array}$ & $\begin{array}{l}\text { Group II } \\
(\text { Mean } \pm \text { SE) }\end{array}$ & $\begin{array}{l}\text { Group III } \\
(\text { Mean } \pm \text { SE) }\end{array}$ & $\begin{array}{l}\text { Group IV } \\
(\text { Mean } \pm \text { SE) }\end{array}$ \\
\hline Total protein $(\mathbf{g m} \%)$ & $5.56 \pm 0.01^{\mathrm{a}}$ & $5.65 \pm 0.02^{\mathrm{a}}$ & $5.82 \pm 0.09^{\mathrm{b}}$ & $5.62 \pm 0.05^{\mathrm{a}}$ \\
\hline Albumin $(\mathbf{g m} \%)$ & $0.64 \pm 0.04^{\mathrm{c}}$ & $0.40 \pm 0.03^{\mathrm{a}}$ & $0.53 \pm 0.02^{\mathrm{b}, \mathrm{c}}$ & $0.55 \pm 0.02^{\mathrm{b}}$ \\
\hline Globulin $(\mathbf{g m} \%)$ & $4.92 \pm 0.05^{\mathrm{a}}$ & $5.25 \pm 0.09^{\mathrm{b}, \mathrm{c}}$ & $5.29 \pm 0.05^{\mathrm{c}}$ & $5.07 \pm 0.06^{\mathrm{a}, \mathrm{b}}$ \\
\hline A : G ratio & $0.13 \pm 0.01^{\mathrm{c}}$ & $0.08 \pm 0.01^{\mathrm{a}}$ & $0.1 \pm 0.01^{\mathrm{b}}$ & $0.11 \pm 0.01^{\mathrm{b}}$ \\
\hline
\end{tabular}

Experimental groups: Group I (control fishes); Group II ( $\beta$ Glucan treated fishes); Group III (A. hydrophila challenged, prior $\beta$ Glucan treated fishes) and Group IV (A. hydrophila challenged fishes). Similar alphabets within column denote homogenous means due to Duncan's post hoc test at $5 \%$ level of significance.

A significant difference $(\mathrm{p}<0.05 \mathrm{df}=3$ ) was found in Albumin percentage among four different experimental groups of L. rohita (Table 4). Duncan's post hoc test revealed the presence of 3 subsets in case of Albumin percentage. Fishes of group II belonged to different single subsets indicating that there was significant difference in the Albumin percentage when it was compared pair-wise with other groups. Whereas, fishes of group I; III and fishes of group III; IV belonged to a single subset, indicating that there was no significant difference between them when compared pair-wise respectively.

A significant difference ( $\mathrm{p}<0.05 \mathrm{df}=3$ ) was found in Globulin percentage among four different experimental groups of $L$. rohita (Table 4). Duncan's post hoc test revealed the presence of 3 subsets in case of Globulin percentage. Fishes of group I and IV; group II and IV; group II and III belonged to same single subset, indicating that there was no significant difference between them when compared pair-wise respectively.

A significant difference ( $p<0.05 \mathrm{df}=3$ ) was found in the ratio of Albumin and Globulin (A: G) among four different experimental groups of L. rohita (Table 4). Duncan's post hoc test revealed the presence of 3 subsets in case of A: G. Fishes of group I and II belonged to different single subsets indicating that there was significant difference in the $A: G$ when it is compared pair-wise with other 
groups. Whereas, fishes of group III and IV belonged to a single subset, indicating that there was no significant difference between them when compared pair-wise.

In this study, total protein content and globulin content increased in the fish after $\beta$-glucan administration and the value was found to be highest in the $A$. hydrophila challenged, $\beta$ glucan treated fishes. Increased level of serum total protein could also be an indication of antibody production in moribund fish with infectious diseases [51]. As the serum proteins include various humoral elements of the non-specific immune system, high concentrations of total serum protein and globulin might be due to the stimulatory functioning of nonspecific immune response of fishes against the bacterial infection after $\beta$ glucan administration. However, the albumin level and the albumin/globulin ration was decreased in group II fishes and it was finally shown to increase after A. hydrophila infection in both group III and group IV fishes which was in accordance with [52].

\section{Conclusion}

Thus, from the present experiment, it is clear that $\beta$ - glucan has an enhancing effect on immunity, growth and survival of $L$. rohita fingerlings. These findings indicate that the use of immunostimulants could represent a potential alternative and/or supplement to chemotherapy and vaccination for maintaining fish health by means of an eco-friendly prophylactic approach.

One of the good sources of $\beta$-glucan is yeast that is a well studied microorganism whose culturing conditions are very well known. From the biotechnological standpoint that would be an advantage because large amount of cheap yeast biomass could be easily grown and growth conditions could be adjusted to maximize $\beta$-glucan yield.

Administration of glucans through various routes including immersion, feed or injection have been found to enhance many types of immune responses, resistance to bacterial and viral infections and resistance to environmental stress. Development of more efficient administration methods will facilitate the routine and prophylactic use of glucans as natural immunostimulants of fish. The limited knowledge of mechanisms of glucan action on fish immunity does not currently allow better and morespecific use of glucan in aquaculture.

Lately, interest focused on mechanisms of action. However, nothing conclusive can be reached as a result of these studies and the effects of glucan on modulation of gene expression leading to stimulation of fish immunity still require elucidation.

However, further work is needed to determine the timing of glucan administration, antigen immunization depending on the response of receptors towards immunostimulants and to ascertain to what extent the increase in complement and lysozyme might influence the ability of fish to cope with stress or disease in intensive culture conditions.

\section{ACKNOWLEDGEMENT}

The authors would like to thank Dr. P. Bag, Department of Biochemistry, University of Calcutta for kindly extending instrumentation facility. S.D.R. is supported by a University Grants Commission sponsored Minor Research Project (No.F. PSW- 22/12-13 (ERO) dated 05.02.2013).

\section{REFERENCES}

[1] Food and Agriculture Organization of the United Nations, (FAO); Fishery Statistics 2010.

[2] Camus, A. C., Durborow, R. M., Hemstreet, W. G., Thune, R. L. and Hawke, J. P. Aeromonas bacterial infections - motile aeromonad septicemia. Southern Regional Aquaculture Centre (SRAC). 1998. Publication No. 478, (1 - 4).

[3] Saha D. and Pal J. Bacteriological Studies on Fishes Affected with Epizootic Ulcerative Syndrome. Asian Fisheries Science. 2000. 13343 - 355.

[4] Vivekanandhan G., Hatha A. A. M. and Lakshmanaperumalsamy P. Prevalence of Aeromonas hydrophila in fish and prawns from the seafood market of Coimbatore, South India. Food Microbiology. 2005. 22(1) 133 - 137. 
[5] Dash S., Swain P., Swain M. M., Nayak S. K., Behura A., Nanda P. K. and Mishra B. K. Investigation on Infectious Dropsy of Indian Major Carps. 2008. Asian Fisheries Science. 21(4) 377 - 384.

[6] Khemiss F., Massoudi R., Ahmadi S., Ghoul-Mazgar S., Safta S., Moshtaghie A. A. and Saidane D. (2008). Aeromonas hydrophila disturbs water and electrolyte transport in Mugil cephalus $L$. intestine. African Journal of Biotechnology. 2008. 7(4) 373 - 380.

[7] Rodríguez I., Novoa B. and Figueras A. Immune response of zebrafish (Danio rerio) against a newly isolated bacterial pathogen Aeromonas hydrophila. Fish and Shellfish Immunology. 2008. 25(3) $239-249$.

[8] Galindo C. L., Sha J., Fadl A. A., Pillai L. L. and Chopra A. K. Host Immune Responses to Aeromonas Virulence Factors. Current Immunology Reviews. 2006. 2(1) 13 - 26.

[9] Harikrishnan R. and Balasundaram C. Modern Trends in Aeromonas hydrophila Disease Management with Fish. Reviews in Fisheries Science. 2005. 13(4) 281 - 320.

[10] Liu P. R., Plumb J. A., Guerin M. and Lovell R. T. Effect of megalevels of dietary vitamin C on the immune response of channel catfish Ictalurus punctatus in ponds. Diseases of Aquatic Organisms. 1989. 7191 - 194.

[11] Bagni M., Archetti L., Amadori M. and Marino G. Effect of Long-term Oral Administration of an Immunostimulant Diet on Innate Immunity in Sea Bass (Dicentrarchus labrax). Journal of Veterinary Medicine. 2000. 47(10) $745-751$.

[12] Sahoo P. K. and Mukherjee S. C. Effect of dietary $\beta$ - 1, 3 glucan on immune responses and disease resistance of healthy and aflatoxin B1-induced immunocompromised rohu (Labeo rohita Hamilton). Fish and Shellfish Immunology. 2001. 11(8) 683 - 695.

[13] Sobhana K. S., Mohan C. V. and Shankar K. M. Effect of dietary vitamin C on the disease susceptibility and inflammatory response of mrigal, Cirrhinus mrigala (Hamilton) to experimental infection of Aeromonas hydrophila. Aquaculture. 2002. 207(3 - 4), 225 - 238.

[14] Harikrishnan R., Nisha R. M. and Balasundaram C. Hematological and biochemical parameters in common carp, Cyprinus carpio, following herbal treatment for Aeromonas hydrophila infection. Aquaculture. 2003. 221(1 - 4) 41 - 50.

[15] Cook, M. T., Hayball, P. J., Hutchinson, W., Nowak, B. F. and Hayball, J. D. Administration of a commercial immunostimulant preparation, EcoActiva as a feed supplement enhances macrophage respiratory burst and the growth rate of snapper (Pagrus auratus, Sparidae (Bloch and Schneider) in winter. Fish and Shellfish Immunology. 2003. 14(4) 333 - 345.

[16] Karata S., Dugenci. A. N. and Candan A. Some medicinal plants as immunostimulant for fish. Journal of Ethnopharmacology. 2003. 88(1) 99 - 106.

[17] Selvaraj V., Sampath K. and Sekar V. Administration of yeast glucan enhances survival and some non-specific and specific immune parameters in carp (Cyprinus carpio) infected with Aeromonas hydrophila. Fish and Shellfish Immunology. 2005. 19(4) 293 - 306.

[18] Bricknell I. and Dalmo R. A. The use of immunostimulants in fish larval aquaculture. Fish and Shellfish Immunology. 2005. 19457 - 472.

[19] Rao Y. V., Das B. K., Jyotyrmayee P. and Chakrabarti R. Effect of Achyranthes aspera on the immunity and survival of Labeo rohita infected with Aeromonas hydrophila. Fish and Shellfish Immunology. 2006. 20263 - 273.

[20] Gopalakannan A. and Arul V. (2006). Immunomodulatory effects of dietary intake of chitin, chitosan and levamisole on the immune system of Cyprinus carpio and control of Aeromonas hydrophila infection in ponds. Aquaculture. 2006. 255179 - 187.

[21] Kumar R., Mukherjee S. C., Prasad K. P. and Pal A. K. Evaluation of Bacillus subtilis as a probiotic to Indian major carp Labeo rohita (Ham.). Aquaculture Research. 2006. 37(12) 1215 1221.

[22] Russo R., Yanong R. P. E. and Mitchell H. Dietary Beta-Glucans and Nucleotides Enhance Resistance of Red-Tail Black Shark (Epalzeorhynchos bicolor, fam. Cyprinidae) to Streptococcus iniae Infection. Journal of the World Aquaculture Society. 2006. 37(3) 298 - 306. 
[23] Abdelkhalek, N. K. M., Zaki, V. H. and Yousef, M. A. A. Effect of some immunostimulants on health status and disease resistance of Nile tilapia. (Oreochromis niloticus). 8th International Symposium on Tilapia in Aquaculture. 2008. 1073 - 1088.

[24] Das B. K., Debnath C., Patnaik P., Swain D. K., Kumar K. and Misrhra B. K. Effect of beta glucan on immunity and survival of early stage of Anabas testudineus (Bloch). Fish and Shellfish Immunology. 2009. 27678 - 683.

[25] Harikrishnan R., Balasundaram C., Moon Y. G., Kim M. C., Kim J. S. and Heo M. S. Use of herbal concoction in the therapy of goldfish (Carassius auratus) infected with Aeromonas hydrophila. Bulletin of the Veterinary Institute in Puławy. 2009. 53(1), 27 - 36.

[26] Yin G., Ardó L., Thompson K. D., Adams A., Jeney Z. and Jeney G. Chinese herbs (Astragalus radix and Ganoderma lucidum) enhance immune response of carp, Cyprinus carpio, and protection against Aeromonas hydrophila. Fish and Shellfish Immunology. 2009. 26(1) 140 145.

[27] Rodríguez I., Chamorro R., Novoa B. and Figueras A. $\beta$-Glucan administration enhances disease resistance and some innate immune responses in zebrafish (Danio rerio). Fish and Shellfish Immunology. 2009. 27(2) 369 - 373.

[28] Barker, D. and Holliday, J. Blood Lymphocyte and Neutrophil Response of Cultured Rainbow Trout, Oncorhynchus mykiss, Administered Varying Dosages of an Oral Immunomodulator 'Fin-Immune TM'. World Academy of Science, Engineering and Technology. 2009. 49.

[29] Lim, C., Yildirim - Aksoy, M., Welker, T., Klesius, P. H. and Li, M. H. Growth Performance, Immune Response, and Resistance to Streptococcus iniae of Nile Tilapia, Oreochromis niloticus, Fed Diets Containing Various Levels of Vitamins C and E. Journal of the World Aquaculture Society. 2010. 41(1) $35-48$.

[30] Sang H. M. and Fotedar R. Effects of dietary $\beta-1,3$ - glucan on the growth, survival, physiological and immune response of marron, Cherax tenuimanus (smith, 1912). Fish and Shellfish Immunology. 2010. 28(5 - 6) 957 - 960.

[31] Pelczar Jr M. J.,Chan E.C.S and Krieg N.R. 2008. Microbiology. $5^{\text {th }}$ Edition. Tata Mc Graw Hill Publishing Company Limited, New Delhi.

[32] Pal J. and Pradhan K. Bacterial involvement in ulcerative condition of air-breathing fish from India. Journal of Fish Biology.1990. 36833 - 839.

[33] Pal S., Ray S. D. and Homechaudhuri S. Evaluation of in vivo non-specific immunity and oxidative stress in Labeo rohita (Hamilton, 1822) infected with Aeromonas hydrophila as biomarker for early diagnosis. International Journal of Fisheries and Aquatic Studies. 2015. 3(1) 116-124.

[34] Ricker W. E. 1979: Growth rates and models. Fish physiology. Academic Press, New York, 677743 , volume 8.

[35] Zar, J. H, 1999. Biostatistical Analysis. $4^{\text {th }}$ Edition. Delhi: Pearson Education, Inc.

[36] Lopez N, Cuzon G, Gaxiola G, Taboada G, Valenzuela M, Pascual C, Sanchez A, Rosas C Physiological, nutritional, and immunological role of dietary b-1-3 glucan and ascorbic acid 2monophosphate in Litopenaeus vannamei juveniles. Aquaculture. 2003. 224223 - 243.

[37] Jaramillo F. Jr. and Gatlin, D. M. III. Comparison of purified and practical diets supplemented with or without $\beta$-glucan and selenium on resistance of hybrid striped bass to Strepococcus iniae infection. Journal of the World Aquaculture Society. 2004. 35 245-252.

[38] Misra C.K., Das B.K., Mukherjee S.C. and Pattnaik, P. Effect of long term administration of dietary Beta-glucan on immunity, growth and survival of Labeo rohita fingerlings. Aquaculture. 2006. 255 82- 94.

[39] Ai Q., Mai K., Zhang L., Tan B., Zhang W. and Xu W. Effects of dietary Beta-1,3 glucan on innate immune response of large yellow croaker, Pseudosciaena crocea. Fish and Shellfish Immunology. 2007. 22 394-402.

[40] Adams, D. O. and Hamilton, T. A. The cell biology of macrophage activation. Annual Reviews of Immunology. 1984. (2) 283 - 318. 
[41] Kwak J. K., S. W. Park, J. G. Koo, M. G. Cho, R. Buchholz, and P. Goetz. Enhancement of the non-specific defence activities in carp (Cyprinus carpio) and flounder (Paralichthys olivaceus) by oral administration of Schizophyllan. Acta Biotechnologica. 2003. 23 359-371.

[42] Duncan P.L. and Klesius P.H. Dietary immunostimulants enhance nonspecific immune responses in channel catfish but not resistance to Edwardsiella ictaluri. Journal of Aquatic Animal Health. 1996. 8 241-248.

[43] Rairakhwada D., Pal A.K., Bhathena Z.P., Sahu N.P., Jha A. and Mukherjee S.C. Dietary microbial levan enhances cellular nonspecific immunity and survival of common carp (Cyprinus carpio) juveniles. Fish Shellfish Immunology 2007. 22 477-486.

[44] Griffiths B. B. and McClain O. The role of iron in the growth and hemolysin (Streptolysin S) production in Streptococcus pyogenes. Basic. Microbiology. 1988. 28(7) 427-36.

[45] Rajeswari S. B., Shome R., Mazumder A., Das A., Kumar R. H. and Bujarbaruah K. M. Abdominal dropsy disease in major carps of Meghalaya: Isolation and characterization of A. hydrophila. Current Science. 2005. 88 1897-1900.

[46] Alexander J.B. and Ingram G.A. Noncellular nonspecific defense mechanisms of fish. In: Faisal, M., Hetrick, F.M. (Eds.), Annual Review of Fish Diseases. 1992. (2). Pergamon Press, New York, $223-247$

[47] Engstad R.E., Robertsen B. and Frivold E., Yeast glucan induces increase in activity of lysozyme and complement-mediated haemolytic activity in Atlantic salmon blood. Fish Shellfish Immunol. 1992. 2 287-297.

[48] Matsuyama S., Fujita Y., Sagara K. and Mizushima S. Overproduction, purification and characterization of SecD and SecF, integral membrane components of the protein translocation machinery of Escherichia coli. Biochimica et Biophysica Acta. 1992. 1122 77-84.

[49] Matsuo, K. and Miyazano, I. The influence of long term administration of peptidoglycan on diseases resistance and growth of juvenile rainbow trout. Nippon Suisan Gakkaishi. 1993. 59 1377-1379.

[50] Bagni M., Romano N., Finoia M.G., Abelli L., Scapigliati G., Tiscar P.G., Sarti M., Marino G. Short- and longterm effects of a dietary yeast $\beta$-glucan (Macrogard) and alginic acid (Ergosan) preparation on immune response in sea bass (Dicentrarchus labrax). Fish and Shellfish Immunology. 2005. 18 (4) 311-325.

[51] Rehulka J. and Minarík B. Blood parameters in brook trout Salvelinus fontinalis (Mitchill, 1815), affected by columnaris disease. Journal of Aquaculture Research. 2005. 38(11) 11821197.

[52] Mondal S., Chakraborty I., Pramanik M., Rout D. and Islam S.S. Structural studies on immunoenhancing polysaccharide isolated from mature pods (fruits) of Moringa oleifera (Sajina). Aquaculture. 2004. 101 197-203. 